\title{
Cluster Analysis of the Development Levels of Tourism Economy in Twelve Provinces (Cities) in China's Western Regions
}

\author{
Yajie QIAO \\ Shaannan Eco-economy Research Center \\ Ankang University \\ Ankang, Shaanxi, China
}

\begin{abstract}
In face of the economic "new normal", the western regions must adhere to the concept of "green development" and give great impetus to regional ecotourism, which is an important way for boosting healthy and rapid growth of regional economy. In this paper, the cluster analysis method is used and 16 indicators in four categories established to classify and analyze the current development conditions of tourism economy in twelve provinces (cities) in China's western regions. These twelve provinces (cities) are classified into the regions where the development of tourism economy is mature, stable and at the exploratory stage, respectively. Major factors that affect the development of regional tourism economy are presented and analyzed, and suggestions are offered for the development of tourism economy in these three classes of regions.
\end{abstract}

Keywords-development of tourism economy; western; ecological; cluster; correlation analysis

\section{INTRODUCTION}

The western regions refer to 12 provinces, cities and autonomous regions in China, namely, Shaanxi, Gansu, Ningxia, Xinjiang and Qinghai in Northwest China, Xizang, Chongqing, Sichuan, Yunnan and Guizhou in Southwest China, and Guangxi and Inner Mongolia. The western regions cover an area of about 5.4 million square meters, accounting for $56 \%$ of China's total area, and accommodate more than $1 / 3$ of China's administrative provinces, cities and autonomous regions, with a population that takes up over $28 \%$ of China's total population[1]. Since the western regions boast vast land and abundant natural environmental resources and are also subject to "vulnerable economy" featuring inconvenient transportation, frequent disasters, etc.; therefore, the implementation of the great western development strategy is of great significance to drive sustained economic growth, promote harmonious economic development among different regions and eventually fulfill the goal of common prosperity. At present, the western regions have made great achievements in economic growth, social development, legal construction and environmental improvement. However, in face of the complex macro-environment, the western regions must adhere to a path of "innovative, coordinated, green, open and shared" development, and take fulfilling the goal of building a moderately prosperous society in all respects as a core mission in the "Thirteenth Five-Year" development of the western regions. The unique ecological advantages in the western regions have provided abundant resources for the flourish of tourism; accordingly, tourism in the western regions in recent years has become an important growth point in the improvement of regional economic development. Existing studies discuss the promoting effect of tourism on local economic development mostly with a single indicator or according to historical data, which are lack of comprehensive considerations both qualitatively and quantitatively; also, these studies classify the economic development levels mostly by region. This paper, according to the indicators of development levels of tourism economy, classifies the current development levels of tourism economy in twelve provinces (cities) in the western regions.

\section{EVAlUATION INDICATOR SySTEM AND EVALUATION} METHOD

\section{A. Establishment of Evaluation Indicator System}

As for the method used to evaluate the development level of tourism economy and for the construction of indicator system, currently no consensus has been reached in the academic circles[2]. Based on the investigation into the indicator configurations of various models, the author has, according to the requirement that the evaluation indicator system should have full coverage, reasonable structure, proper complexity and high representativeness and following the scientific, objective, systematic, feasible and comparable principles, set the development levels of tourism economy in twelve provinces (cities) in the western regions to an indicator system consisting of three levels of indicators. It is an evaluation system composed of one Level 1 indicator (i.e., the development level of tourism economy), four Level 2 indicators, and sixteen Level 3 indicators. See Table 1 for the specific indicators.

\section{B. Data Collection and Processing}

All raw data used in this paper come from China Statistical Yearbook 2017 [3] and the provincial statistical yearbooks for 2017; partial data have been acquired through calculations based on the raw data; some missing data are supplemented in the Statistical Communique of the People's Republic of China on the 2016 National Economic and Social Development and the provincial and municipal statistical communiques. The data acquired involve many provinces; individual data are collected and acquired by different means; these data have different dimensions and orders of magnitude, thus cannot be directly 
used for evaluation. Therefore, in order to ensure the reliability of results, it is necessary to standardize the raw indicator data. In this paper, the z-score standardization method is used to convert the values of raw data to new data, thus to eliminate the influence from the difference in data measuring units and to facilitate direct comparison. The formula is expressed as:
New data converted from standardization

$=($ raw data - mean $) /$ standard deviation

TABLE I. EVALUATION INDICATOR SYSTEM FOR THE DEVELOPMENT LEVELS OF REGIONAL TOURISM ECONOMY

\begin{tabular}{|c|c|c|c|}
\hline $\begin{array}{c}\text { Level 1 } \\
\text { indicator }\end{array}$ & Level 2 indicator & Level 3 indicator & Unit \\
\hline \multirow{16}{*}{ 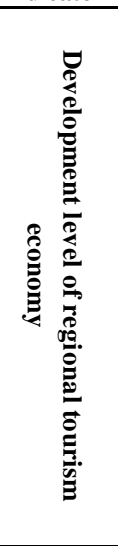 } & \multirow{3}{*}{$\begin{array}{c}\text { Scale of tourism } \\
\text { economy }\end{array}$} & Gross tourism revenue & Billion Yuan \\
\hline & & Proportion of tourism revenue in gross domestic product (GDP) & $\%$ \\
\hline & & Total number of tourists & I \\
\hline & \multirow{5}{*}{$\begin{array}{l}\text { Basic tourism } \\
\text { resources }\end{array}$} & Number of star-rated hotels & 1 \\
\hline & & Number of employed persons in hotels and catering services above designated size & 1 \\
\hline & & Total passenger transport volume & Billion passengers \\
\hline & & Passenger transport turnover & Billion passenger kilometers \\
\hline & & Number of natural reserves & / \\
\hline & \multirow{3}{*}{$\begin{array}{c}\text { Regional economic } \\
\text { development }\end{array}$} & Per capita GDP & Yuan/Person \\
\hline & & Per capita disposable income of urban residents & Yuan \\
\hline & & Per capita disposable income of rural residents & Yuan \\
\hline & \multirow{5}{*}{$\begin{array}{c}\text { Tourism } \\
\text { environmental quality }\end{array}$} & Frequency of natural disasters & Times \\
\hline & & Per capita water resources & m3/person \\
\hline & & Forest coverage & $\%$ \\
\hline & & Annual air quality composite index & 1 \\
\hline & & Air dust emission & Ton \\
\hline
\end{tabular}

\section{Evaluation Method}

In this paper, cluster analysis is used to evaluate the indicator data. Cluster analysis is a statistical method which aims to classify a sample of subjects (or objects) on the basis of a set of measured variables into a number of different groups such that similar subjects are placed in the same group. By cluster analysis, the development levels of tourism economy of different samples are divided into several classes so as to

\section{Clustering Results AND ANAlysis}

\section{A. Hierarchical Clustering Diagram and Classification} SPSS:

Fig.1 shows the dendrogram after data clustering with

$$
\text { Dendrogram using Ward Method }
$$

$$
\text { Rescaled Distance Cluster Combine }
$$

CASE O N
Label Num
Chongqing
Shaanxi
Guizhou
Guangxi
Yunnan
Inner Mongolia
Sichuan
Gansu
Xinjiang
Qinghai
Ningxia
Xizang

Fig. 1. Dendrogram

According to the results shown in Fig.1, the development conditions of tourism economy in twelve provinces (cities) in the western regions can be divided into three classes. The first class refers to Sichuan where the development of tourism economy is mature; the second class includes Chongqing, discover the similarities in the same class and the differences among different classes. This will reflect the current development condition of tourism-driven economy so that appropriate countermeasures and policies can be better studied and developed. Based on hierarchical cluster analysis with SPSS, this paper uses squared Euclidean distance to calculate the similarities among the twelve provinces (cities) in the western regions. The Ward's method is used as the clustering method.

Shaanxi, Guizhou, Guangxi, Inner Mongolia and Yunnan where the development of tourism economy is stable; the third class consists of Gansu, Xinjiang, Qinghai, Ningxia and Xizang where the development of tourism economy is at the exploratory stage.

\section{B. Scale of Tourism Economy and Development of Tourism Economy}

In this paper, three indicators, namely, the gross tourism revenue, the total number of tourists and the proportion of tourism revenue in GDP, are used to represent the scale of regional tourism economy. According to the classification results, the total number of tourists is directly correlated with the development condition of tourism economy. The development of regional tourism economy is first manifested as the expansion of the number of tourists. Therefore, this indicator in Sichuan in the first class is 63333.79, ranking the first. For regions in the second class, this indicator is calculated as the simple arithmetic mean (for the convenience of calculation and the need for explanation, the simple arithmetic mean is used instead of the weighted mean), and the value is 32545.89. For the third class, this indicator is calculated as the simple arithmetic mean, and the value is 7019.64, which is significantly lower. Besides, data provided in this paper are used to analyze the correlation of the per capita GDP with the total number of tourists, the tourism revenue and the proportion 
of tourism revenue in GDP, respectively, and all these indicators fail the correlation test. Thus it can be seen that these three indicators are not critical factors that affect the development of regional tourism economy.

\section{Basic Tourism Resources and Development of Tourism Economy}

Five indicators, namely, the number of star-rated hotels, the number of employed persons in hotels and catering services above designated size, the total passenger transport volume, the passenger transport turnover and the number of natural reserves, are used to represent the condition of basic tourism resources in this region. As can be seen from Table II, Sichuan in the first class stands out in terms of all the above indicators; it is thus clear that the allocation of basic tourism resources can drive the development of regional tourism economy to some degree. However, correlation analysis between the above indicators and the per capita GDP shows that the values of correlation coefficient are all very small or even negative; therefore, these indicators are insignificantly correlated with the development of tourism economy. The proportion of tourism revenue in GDP has a significant correlation with the number of employed persons in hotels and catering services above designated size, the total passenger transport volume and the passenger transport turnover, with the values of correlation coefficient all above 0.6. It is thus evident that the above indicators are extremely important sources of tourism revenue and also determine the significant role of tourism in driving regional economic development (see Table II for details). According to survey findings, for regional economic development driven by tourism in the western regions, consideration should often be given to the characteristics of local economic development and importance attached to sustainability and ecological protection; excessive increase of the allocation of material resources will not necessarily positively promote the development of regional tourism economy.

TABLE II. CLASSIFICATION DAT A OF BASIC TOURISM RESOURCES

\begin{tabular}{|c|c|c|c|c|c|}
\hline & $\begin{array}{c}\text { Number of } \\
\text { star-rated } \\
\text { hotels }\end{array}$ & $\begin{array}{l}\text { Number of employed } \\
\text { persons in hotels and } \\
\text { catering services } \\
\text { above designated size }\end{array}$ & $\begin{array}{c}\text { Total } \\
\text { passenger } \\
\text { transport } \\
\text { volume } \\
\end{array}$ & $\begin{array}{c}\text { Passenger } \\
\text { transport } \\
\text { turnover }\end{array}$ & $\begin{array}{l}\text { Number of } \\
\text { natural reserves }\end{array}$ \\
\hline Value in the first class & 427 & 2667722 & 1282.2 & 168.7 & 169 \\
\hline Simple arithmetic mean in the second class & 371 & 120767 & 399.2 & 68 & 110 \\
\hline Simple arithmetic mean in the third class & 227 & 24067 & 181.2 & 26.9 & 33 \\
\hline Coefficient of correlation with the per capita GDP & -0.366 & -0.065 & -0.007 & -0.062 & 0.137 \\
\hline $\begin{array}{c}\text { Coefficient of correlation with the proportion of } \\
\text { tourism revenue in GDP }\end{array}$ & 0.082 & $0.636^{*}$ & $0.688 * *$ & $0.673^{* *}$ & 0.371 \\
\hline
\end{tabular}

\section{Regional Economic Development and Development of Tourism Economy}

Three indicators, namely, the per capita GDP, the per capita disposable income of urban residents and the per capita disposable income of rural residents, are used to represent the economic development level in this region. According to Table III, the per capita GDP is significantly correlated with the per capita disposable income of urban residents and the per capita disposable income of rural residents, with the correlation coefficients being 0.585 and 0.673 , respectively. From the per capita GDP and the per capita disposable income of urban residents, the biggest arithmetic mean is found in the second class, followed by the first class; for the per capita disposable income of rural residents, the biggest arithmetic mean is found in the first class, followed by the second class (see Table III for details). With consideration to the geographic and geomorphic conditions in Sichuan, the regional economic development driven by tourism should conform to the basic laws and features in the development of mountain area economy and fully mobilize rural and local residents to increase their income through tourism services, which will actively promote the development of local tourism economy.

TABLE III. CLASSIFICATION DAT A OF REGIONAL ECONOMIC DEVELOPMENT

\begin{tabular}{c|c|c|c}
\hline & Per capita GDP & $\begin{array}{c}\text { Per capita disposable income of } \\
\text { urban residents }\end{array}$ & $\begin{array}{c}\text { Per capita disposable income of } \\
\text { rural residents }\end{array}$ \\
\hline Value in the first class & 39695 & 28335.3 & 29117 \\
\hline Simple arithmetic mean in the second class & 47325 & 25283 & 11203.13 \\
\hline Simple arithmetic mean in the third class & 38823 & $0.585^{*}$ & 10004 \\
\hline Coefficient of correlation with the per capita GDP & - & 9050 & \multicolumn{2}{c}{$0.673^{* *}$} \\
\hline \multicolumn{2}{|c}{ Note: * represents that the significance level is $0.05 ; * *$ represents that the significance level is 0.01.}
\end{tabular}

\section{E. Tourism Environmental Quality and Development of Tourism Economy}

Five indicators, namely, the frequency of natural disasters, the per capita water resources, the forest coverage, the annual air quality composite index and the air dust emission, are used to represent the basic condition of tourism environmental quality in this region. It can be seen from Table IV that the per capita GDP has no significant correlation with the above indicators, and the forest coverage is closely correlated with the gross tourism revenue with the correlation coefficient being 0.728. According to survey findings, abundant ecotourism resources, clean air, beautiful environment and rich water resources boasted by the western regions are often the major 
factors attracting numerous tourists, while the forest coverage will directly affect the air quality in the western regions. For these advantages that cannot "go out", many cities present the "bring in" strategy in diversified forms such as homestay, health \& wellness and folk custom experience to directly increase the tourism revenue. Therefore, for the western regions, the forest coverage and other ecological environmental resources are critical factors that affect the development of regional tourism economy.

TABLE IV. CLASSIFICATION DAT A OF TOURISM ENVIRONMENT AL QUALITY

\begin{tabular}{|c|c|c|c|c|c|}
\hline & $\begin{array}{c}\text { Frequency of } \\
\text { natural disasters }\end{array}$ & $\begin{array}{c}\text { Per capita water } \\
\text { resources }\end{array}$ & $\begin{array}{c}\text { Forest } \\
\text { coverage }\end{array}$ & $\begin{array}{l}\text { Annual air quality } \\
\text { composite index }\end{array}$ & $\begin{array}{l}\text { Air dust } \\
\text { emission }\end{array}$ \\
\hline Value in the first class & 227 & 2843.31 & 35.2 & 6.1 & 272680.8 \\
\hline Simple arithmetic mean in the second class & 146 & 2721 & 41 & 5 & 282679 \\
\hline Simple arithmetic mean in the third class & 62 & 31502 & 9 & 5 & 200662 \\
\hline $\begin{array}{l}\text { Coefficient of correlation with the per capita } \\
\text { GDP }\end{array}$ & -0.433 & -0.220 & 0.007 & 0.282 & 0.492 \\
\hline $\begin{array}{c}\text { Coefficient of correlation with the gross } \\
\text { tourism revenue }\end{array}$ & 0.407 & -0.344 & $0.728^{* *}$ & -0.457 & 0.070 \\
\hline
\end{tabular}

\section{CONCLUSIONS AND SUGGESTIONS}

In this paper, division is not simply made by geographical location which is a traditional method; instead, 16 indicators in four categories are used to classify, by clustering according to the development condition of tourism economy, the twelve provinces (cities) in the western regions into the regions where the development of tourism economy is mature, stable and at the exploratory stage, respectively.

The number of employed persons in hotels and catering services above designated size, the total passenger transport volume and the passenger transport turnover serve as important basic conditions for the development of regional tourism economy, and increasing the allocation of these resources will provide necessary material guarantee for the development of local tourism economy. Besides, the forest coverage and the disposable income of residents are important factors to realize regional tourism development; the former creates a good ecological environment and the latter provides financial support for such development. Therefore, the improvement of the above factors will significantly affect the development level of regional tourism economy.

According to data of provinces (cities) in the western regions, the total number of tourists and the gross tourism revenue do not necessarily indicate high development level of regional tourism economy; the number of natural reserves and the number of star-rated hotels are not critical factors that affect the development of tourism economy, therefore should not be used as excuses for the lagged development of tourism economy. From the air quality index in the provinces (cities) in the western regions, it can be seen that the development of tourism economy is accompanied by the deterioration of air quality and the increase of emissions. It is suggested that the regions concerned should take targeted improvement measures to keep sustainable and healthy development of tourism economy.

\section{REFERENCES}

[1] Wang Xiaofe,"New Thoughts on Ecotourism Development in China's Western Regions”West China Development, 2011.05,pp.217.( In Chinese)

[2] Sun Xiaodong, Feng Xuegang,"Multi-Criteria Similarity and Spatial Cluster of Provincial Tourism Economic Development in China," Journal of Natural Resources, 2015.01(1),pp.51-61. ( In Chinese)

[3] National Bureau of Statistics. China Statistical Yearbook [DB/OL].http://data.stats.gov.cn/

[4] Wang Fengjiao. Research on the Difference in Regional Tourism Economy among Beijing, Tianjin and Hebei and the Influential Factors [D]. Yanshan University, 2016. ( In Chinese)

[5] Mo Yankai, "Comprehensive Evaluation of the Difference in Development of County Tourism Economy - A Case Study of Lishui”, Tourism Economy, 2012(03), pp.133-136. ( In Chinese)

[6] Hao Mengyao,"Principal Component of China’s Inbound Tourism Market and Cluster Analysis," Economic Development Research, 2017.04,pp.199-120. ( In Chinese)

[7] Zhang Guanghai, Ding Qiuyue, “Analysis on the Tourism Develop ment of the Tourist City Clusters in the Yangtze River Delta Based on Cluster Analysis," Journal of Qingdao University of Science and Technology (Social Science Edition), 2018, (2),pp.1-5. ( In Chinese) 